\title{
Zenon Jasiński, Kazimierz Rędziński, Polscy uchodźcy i polskie szkoly w Czechach i na Morawach w czasie I wojny światowej, Instytut Nauk Pedagogicznych Uniwersytetu Opolskiego, Opole
}

1985, ss. 104

Materiał zawarty w książce podzielony jest na dwie części. Pierwsza część „Polscy uchodźcy i wysiedleńcy w Czechach i na Morawach po wybuchu I wojny światowej”, a druga „Polskie szkolnictwo na uchodźstwie w Czechach i na Morawach w latach I wojny światowej".

W pierwszej części autorzy opisuja przyczyny i rozmiary masowej migracji ludności polskiej w momencie wybuchu I wojny światowej. Przedstawiają problemy $z$ jakimi zetknęli się uchodźcy na nowych terenach. Opisują również stosunek mieszkańców miast i miasteczek Czech, Moraw, Styrii i Dolnej Austrii do uchodźców. Część ta przedstawia trudności życia różnych grup, w tym dużej grupy Polaków pochodzenia żydowskiego. Autorzy w tym rozdziale opisują: zaskoczenie władz austro-węgierskich rozmiarami uchodźstwa, jak również stopniowe tworzenie sie instytucji niosących pomoc ewakuowanej i wysiedlonej ludności polskiej, organizacje życia, kształcenia i wychowania w warunkach wojennych.
Druga część publikacji ukazuje chaos w organizacji szkolnictwa polskiego w Czechach i na Morawach spowodowany przedłużającą się wojną. Czessć ta zawiera informacje: o kadrze nauczycielskiej, ilości szkolnych oddziałów, realizowanych przedmiotach, programach nauczania, profilach szkół, organizacji kursów dla młodzieży pozaszkolnej i nauczycieli, formach prowadzenia egzaminów dojrzałości, oraz wykaz miejscowości, w których powstały polskie szkoły. W tej części autorzy opisują również szkolnictwo żydowskie, rodzaje szkót, programy nauczania, programy pracy wychowawczej, rozmieszczenie szkół. Duży fragment publikacji zawiera dane o działalności Komitetu Szkolnego i Polskiego Inspektoratu Szkolnego w Pradze. Końcowy fragment książki przedstawia trudności związane z prowadzeniem i organizowaniem szkół polskich na terenie Cesarstwa Austro-Węgierskiego. Publikacja jest bogato ilustrowana fotografiami $z$ tamtego okresu.

Andrzej Litwin

\section{Stefania Walasek, Szkolnictwo średnie ogólnoksztalcące na zie- miach polskich w latach 1914-1923, Wydawnictwo Uniwersytetu Wroclawskiego, Wroclaw 1996, ss. 260}

W 1996 roku Wydawnictwo Uniwersytetu Wrocławskiego opublikowało, cenną dla historii oświaty, pracę Stefanii Walasek Szkolnictwo srednie ogólnoksztalcqce na ziemiach polskich w latach 1914-1923. Rozprawa ta ma duże znaczenie dla badań nad dziejami oświaty, gdyż wypetnia lukę $w$ opracowaniach dotyczących historii szkolnictwa średniego okresu I wojny światowej i pierwszych lat II Rzeczypospolitej.

Jako zasadnicze zagadnienia tej pracy można wyróżnić:
- wpływ polityki władz zaborczych i okupacyjnych (lata 1914-1918) na funkcjonowanie polskiego i mniejszościowego szkolnictwa średniego;

- wpływ wydarzeń politycznych i militarnych (lat 1918 - 1921) na losy szkolnictwa średniego;

- rola społeczeństwa polskiego $w$ obronie i organizowaniu szkolnictwa średniego w latach 1914-1921;

- proces przejmowania szkół przez Ministerstwo Wyznań Religijnych i Oświecenia Publicznego; 